\title{
The Role of Accounting Information, Job Satisfaction, and Organizational Commitment to Job Performance through Organizational Citizenship Behavior (OCB) (Studies in Small and Medium Enterprises in Southeast Sulawesi)
}

\author{
Husin and Nurwati \\ Fakultas Ekonomi dan Bisnis, Universitas Halu Oleo, Southeast Sulawesi Indonesia 93232
}

\begin{abstract}
This study aimed to assess the effect of variable accounting information, job satisfaction, organizational commitment, and $O C B$ on job performance in small and medium enterprises in Southeast Sulawesi.The population of this study were all small and medium enterprises in Southeast Sulawesi; with a target population or target of the study are employees of small and medium businesses. The samples were permanent employees, the employee sampled using stratified random sampling method.

The results of this study showed that the discussion of accounting information, job satisfaction and organizational commitment mediated by organizational citizenship behavior, contribute to the improvement of job performance. OCB thus able to provide a stimulus for improving job performance. Concluded: Small and Medium Enterprises in Southeast Sulawesi province that performs well on an ongoing basis is the SMEs that successfully increased employee Organizational Citizenship Behavior in the end make an effective contribution to the survival of the organization.
\end{abstract}

Keywords: accounting information, job satisfaction, organizational commitment, organizational citizenship behavior $(O C B)$, job performance.

\section{Introduction}

Accounting information as a measure in evaluating job performance work commitments and has invited a series of debates which led the researchers to conduct research in this field. The use of accounting information as a tool to assess one's accomplishments were first developed by (Siegel et al. 1989), which examines the consequences of the use of accounting information as a tool to assess the performance of subordinates.

More research in related antecedents that shape the behavior of OCB among others conducted by Bateman and Organ 1983, Puffer, 1987, Bolon, 1997, Jose et al, 2005, Sangmookim, 2006 study that examines the relationship between OCB on performance is Markt et al. (2002), they found that organizational citizenship behavior (OCB) has a positive relationship with organizational performance, resulting also that OCB is very important because it helps build social capital, which in turn improves performance.

Petrus (2005) states accounting information has a significant influence on the performance of employees. Companies with accounting information significantly influence behavior and better performance and more effective. Performance related to the culture and design of management control based on culture (Bimberg, 2004; Brigibe, 2007; and Bernard 2010). This statement is consistent with the Contingency Theory of organization (Hall, 1978) which states that in the context of the organizational structure of the organization, can affect performance. Testing direct and control management culture together can affect the performance of the company. The results of the survey conducted research (Lawrence et al., 2009); Birnberg and Snograss, 1988) found differences in behavior and culture influence the effectiveness of management information.

The results of the research on accounting information and work behavior by Suroso (2003), Takiyuddin (2003), and Kinard (1970) concluded that there is a positive effect between accounting information and work behavior. Based on the description above, the proposed hypothesis that the more adequate accounting information, it can improve work behavior.

Koys (2001) found job satisfaction and OCB effect on employee effectiveness. Yoon and Suh (2003) found that job satisfaction significantly influence citizenship behavior (OCB). Begum (2005) states that high job satisfaction will affect the bank employee OCB. Gonzales and Garazo (2006) found a positive relationship between job satisfaction and OCB.Felfeet et al. (2007), found that the commitment of the new forms of influence on OCB and organizational commitment mediates the relationship between the form of new jobs and Outcome. Lun and Huang (2007) found that organizational commitment moderates the relationship between age and job performance and low commitment significant negative effect on performance. While Foote and Tang (2008) found that the effect on the team's commitment and OCB relationship between job satisfaction and OCB is moderated by a team commitment. 
This study, on performance and job satisfaction have also been made by Morris and Miebuhr (1994) study found that against a strong and significant relationship between job satisfaction variables internally oriented individuals nevertheless the level of performance and job satisfaction between internal and external is relatively constant. However, the relationship between performance and job satisfaction are significantly different for individuals who have a payment and also support the promotion of boss will make employees more motivated to improve skills, skills and abilities and the motivation of employees will also increase the quality of neatness, accuracy and skills that will impact on performance.

Accounting information and performance research done by (Siegel etal.1989), Hopwood(1972), Dona(2011), and Salomi (2008), Biswas and Varma (2007), concluded that the accounting information significant effect on performance. Based on the above description of the proposed research hypothesis is more adequate management control can improve the performance of employees.

Testing the research model used path analysis using the software LISREL 8. The results of this study was to test a model of commitment from Randall and Cote (1991) is fully supported, except for the relationship and job involvement and sustained commitmen. This relationship is better understood through a career commitment. An important finding of this study is that the role of job satisfaction mediates the relationship between work commitment and job performance

Research from Mackenzie et al., (1996), Walz \& Niehoff, (1996); Padskoff et al., (1997), found that helping behavior (helping behavior) can improve organizational performance. Yoon and Suh (2003) found that OCB affects the quality of service (quality service). Similarly, Douglas S. Bolon (1997) to the research findings support the hypothesis that the perception of the psychological climate in the organization has a positive and significant impact on their willingness to participate in OCB as well as on the level of satisfaction of their work, in addition to the OCB and job satisfaction has an impact significantly to the performance of the individual.

\section{Methods}

\section{Research Design}

In accordance with the research objectives have been formulated, this study uses the pattern of explanatory research is research that is intended to explain the position of the variables studied and the relationship and influence of one variable with another variable (Sugiono, 2004). The research location is selected in this study is the research object of Southeast Sulawesi province are Small and Medium Enterprises.

The population of this study were all small and medium enterprises in Southeast Sulawesi with a target population or target of the study is small and medium businesses. Sampling method used was purposive sampling. The samples of employees, while the employees in the study group consisted of permanent employees who are already working in the company for at least 5 years and older. Samples were permanent employees, using stratified random sampling method. The amount of sample used was determined by the approach Yamane (1973) in Ferdinand (2006) Defined by 5\% by the formula of Slovin in Umar (2004).

\section{Research Models and Analysis}

The data were analyzed by means of statistical analysis through the use of structural equation modeling (SEM). SEM is a structural equation model was used to test the effect of independent variables on the dependent variable or one hypothesis to test hypothesis seven. In this study using AMOS software or Lisrell which is one of the most widely used programs in the SEM models. Lisrell software will be used if the data obtained from the study of Likert did not meet the assumptions of normality that require data transformation.

\section{Research Hypothesis Testing Results}

\section{Hypothesis Testing Results and Discussion Research}

The results of hypothesis testing using Structural Equation Modeling (SEM) revealed that the six hypotheses declared significant and one hypothesis is not significant. Hypothesis testing is done by looking at the coefficient of the standard, the value of the $t$ test of significance and sign of the relationship of each independent variable on the dependent variable partially. The results of hypothesis testing are shown in Table 1.

\section{Discussion of Research \\ Effect of Accounting Information on Organizational Citizenship Behavior}

The analysis showed that the accounting information has a positive and significant influence on OCB and these results prove that the hypothesis that the better the accounting information, the employee will increase OCB acceptable. It shows that a good accounting information will be able to improve the behavior of employees in the work to create effective for the continuity of the organization. 
The Role of Accounting Information, Job Satisfaction, and Organizational Commitment to ....

Table 1 Results of Hypothesis Testing

\begin{tabular}{|l|l|l|l|l|}
\hline \hline Independent Var. & Dependent Var. & Coefficient & P- Value & Result \\
\hline Accounting Information $\left(\mathrm{X}_{1}\right)$ & OCB $\left(\mathrm{Y}_{1}\right)$ & 0,909 & 0,00 & Significant \\
\hline Job Satisfaction $\left(\mathrm{X}_{2}\right)$ & OCB $(\mathrm{Y} 1)$ & 0,739 & 0,048 & Significant \\
\hline Organizational Commitment $(\mathrm{X} 3)$ & OCB $\left(\mathrm{Y}_{1}\right)$ & 0,900 & 0,000 & Significant \\
\hline Job Satisfaction $(\mathrm{X})$ & Job Performance $\left(\mathrm{Y}_{2}\right)$ & 0,330 & 0,000 & Significant \\
\hline Accounting Information $(\mathrm{X} 1)$ & Job Performance $\left(\mathrm{Y}_{2}\right)$ & 0,444 & 0,000 & Significant \\
\hline Organizational Commitment $(\mathrm{X} 3)$ & Job Performance $\left(\mathrm{Y}_{2}\right)$ & 0,015 & 0,927 & Not Significant \\
\hline OCB $\left(\mathrm{Y}_{1}\right)$ & Job Performance $\left(\mathrm{Y}_{2}\right)$ & 0,488 & 0,000 & Significant \\
\hline \hline
\end{tabular}

Source: Primary data is processed, 2014

Model of the relationship between the independent variables and the dependent variable are presented in Figure 1 as follows:

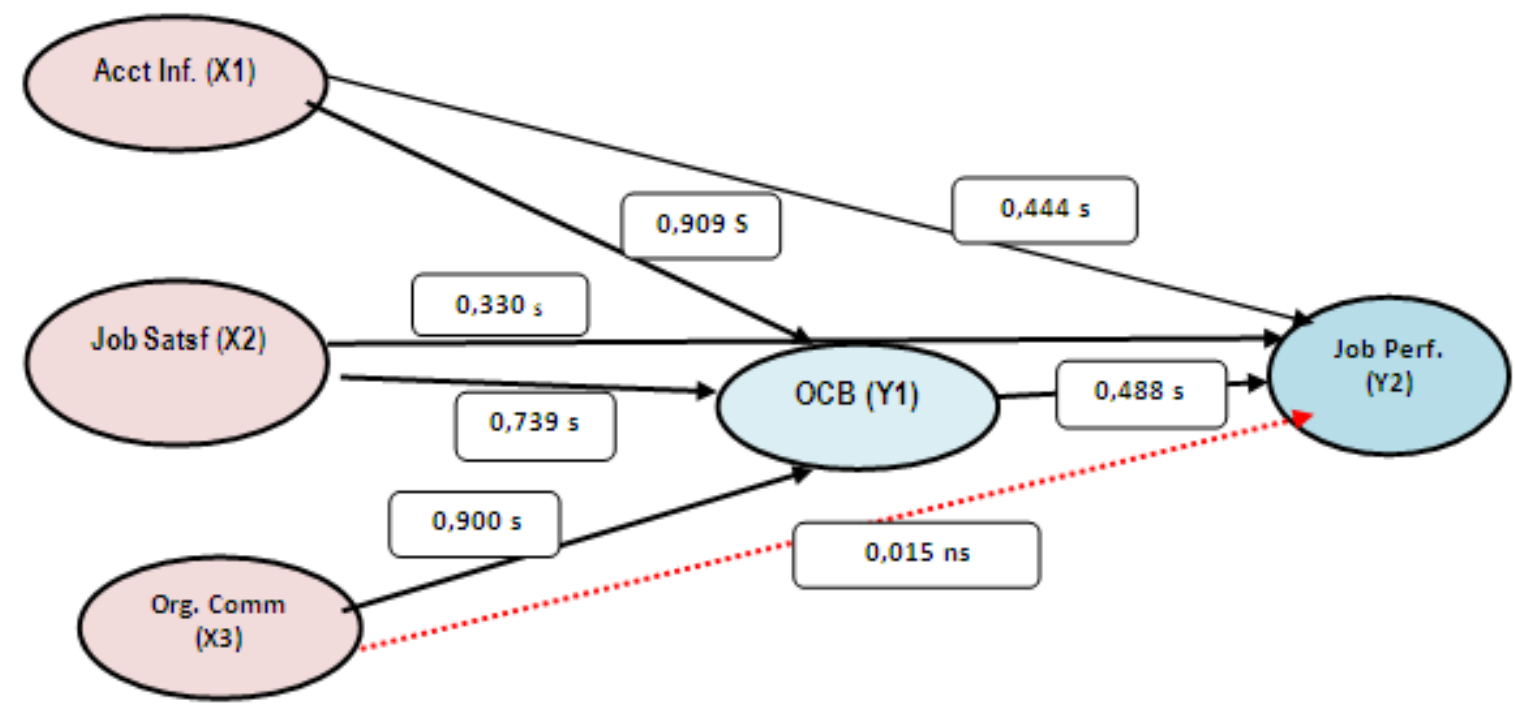

Description: $\mathrm{s}=$ significant path, $\mathrm{ns}=$ non-significant path

Figure 1. Diagram of Hypothesis Testing

Research findings that support this research as stated by Siegel et al. (1989), Hopwood (1972), Dona. (2011), and Salomi (2008), Soumendu Arup Biswas and Varma (2007), the researchers concluded that the accounting information have a significant effect on performance.

\section{Effect of Job Satisfaction on Organizational Citizenship behavior (OCB)}

The analysis showed that job satisfaction has a significant positive effect on Organizational Citizenship Behavior and these results prove that the hypothesis that the higher the job satisfaction of employees, the employees will show an increase organizational citizenship behavior acceptable. It shows that employees who are satisfied will be more likely to speak positively about the organization, their sensitivity to help co-workers and make their job performance beyond the normal estimates, more than that satisfied employees are more obedient to the call of duty (Robbins, 2006).

Research Yoon and Suh (2003) found that job satisfaction significantly influence OCB, research by Begum (2005) also states that the higher the job satisfaction will increase employee OCB. Later studies also support the results of studies conducted by Jose Vareela et al. (2006), George Murphy et al. (2002), Biswas and Varma (2007).

\section{Effect of Organizational Commitment on Organizational Citizenship Behavior}

The analysis showed that organizational commitment and significant positive effect on OCB. These results prove the hypothesis that the higher the organizational commitment to give an increase in OCB. Employees who have a high commitment to the organization is able to improve the behavior of OCB because employees feel have an emotional attachment to the organization, are willing to spend the rest of his career in the organization and have a strong sense of belonging to the organization.

This study confirms that high commitment towards the organization is able to create employee OCB. These findings support research conducted by Mowday et al (1979) who explains that organizational commitment means the relative strength of an individual's identification with the organization's involvement in 
the present something more than mere passive loyalty to the organization's commitment and involves active relationship with the organization, so that the individual gives something of himself for the benefit of the organization. Commitment is not only obtained from the beliefs and opinions of individuals, but also of his actions.

Angle and Perry (1981) found two sub-scales: commitment value, which reflects a commitment to support the organization's goals and commitment to survive, which reflects a desire to maintain organizational membership. Meyer and Allen (1984) used the term affective commitment and sustained commitment to measure the attitudes and behavior of the view. Meyer and Allen (1991) identified three components of organizational commitment, namely affective commitment, continuous commitment and normative commitment is the determinant of OCB, O 'Reilley and Chatman (1986) found that identification was a significant predictor of Self-Report compliance of extra role behavior.

\section{Effect of Job Satisfaction on Job Performance}

The analysis showed that job satisfaction has positive influence on job performance. With this result proves that the hypothesis that the higher the job satisfaction will increase job performance. Gibson et al (1997) found that high job satisfaction will be able to create high performance.

Likewise, the results of research and Anat Freund Carmely Abraham (2001) research results showed that job satisfaction has a role on the performance, Biswas and Varma (2007) in this study using data from 357 employees in managerial get the manufacturing and services sectors in Indian participation of 357180 participants or $42 \%$ of which comes from public sector organizations while 177 or $49.58 \%$ were service sector organizations results of this study support the hypothesis that job satisfaction has a significant impact on the performance of the individual. This study also supports research of Yousep (2000) and Gregory Murphy (2001).

\section{Effect of Accounting Information on Job Performance}

The analysis showed that the accounting information has a positive and significant impact on job performance. The results of the hypothesis that the better the accounting information it will increase the performance of employees who accepted the truth. Coefficient is positive and significant path means there is a relationship between the direction of accounting information with job performance. These results are interesting to study further, because in general the theoretical accounting information that can improve job performance.

This is in line with the accounting information and performance research done by ( $\mathrm{Si}$ 1 ege, G. Et a l. 1989), Hopwood (1972), Don a. (2011), and Salomi (2008), Biswas and Varma (2007), concluded that the accounting information significant effect on performance. Based on the above description of the proposed research hypothesis is better accounting information can improve the performance of employees. Test results are not a direct influence on the performance of accounting information through OCB with path coefficients greater than the direct effect of accounting information on the performance of the employees, so that the effect of accounting information on performance through OCB effect meaningful and full of character as an intervening variable (fully intervening). However, this research is supported by the research MT Suliman (2001) who studied the retailers that links accounting information with the performance. Based on the research results of accounting information has a significant influence on job performance.

\section{Effect of Organizational Commitment on job performance.}

The analysis showed that organizational commitment has a positive and insignificant effect on job performance. These results prove that the hypothesis that the higher the organizational commitment will increase job performance, although not significant. This suggests that organizational commitment is comprised of; affective commitment, continuous commitment and normative commitment are owned by the employees working in SMEs are less able to improve job performance.

The results of this study are not in line with the opinion of Allen and Meyer (1997) and Luthans (2006). Allen and Meyer said that the organization's commitment to strengthen or improve job performance. While Luthans (2006) mentions that there has been a lot of research that supports the positive relationship between organizational commitment to high performance. The results of this study empirically supports research lyn and Martin (1989) they concluded that organizational commitment has a positive and significant impact on the performance of employees, which means the higher the level of commitment the organization will increase job performance.

\section{The influence of organizational citizenship behavior on job performance.}

From the results of the analysis indicate that OCB positive and significant effect on the performance of employees and support the research hypothesis that states that the higher the employee OCB increasing job performance is acceptable. This means that a good employee behavior will contribute to the improvement of the performance of the employee, because the employee voluntarily wish to participate in and support functions of 
the organization and have a high sensitivity to help colleagues in need, because this behavior is a work behavior that exceeds their formal duties without expecting acknowledgment or compensation and contribute to organizational effectiveness.

These results also support the study of George et al (1992) found a close relationship between OCB to group performance. The existence of altruistic behavior that allows a group to work in a compact and effective for mutual cover each other's weaknesses (Podsakoff, 1997). S.Balon Douglas (1997) in his study explains that OCB and job satisfaction have a significant impact on the performance of the individual. Biswas and Varma (2007) explains that OCB had a significant impact on the performance of the individual.

\section{Conclusion}

\section{Conclusions and Recommendations}

Good accounting information leads to a higher organizational citizenship behavior of employees, so it will create better punctuality in work, meaning that a good accounting information according to the perspective of the employees through the relevance of the work, are able to form peer support organizational citizenship behavior of employees increased.

Job satisfaction felt by employees can increase employee organizational citizenship behavior. This means that high job satisfaction as well as support to the payroll supervisor is able to improve the organizational citizenship behavior of employees in small and medium enterprises in the province of South East Sulawesi. An increase in employee satisfaction over salary payment is received and support supervisors make employees more motivated in improving organizational citizenship behavior for the better by being more actively pursue its work in accordance with its responsibilities, increase social sensitivity to help his co-workers and avoid behaviors that can detrimental to the organization.

Commitment to the organization to encourage individual employees to show organizational citizenship behavior This suggests that employees have identification with the organization, in other words, feel a part of their organization and have a positive organizational commitment, which in turn employees to the existing Small and Medium Enterprises in Southeast Sulawesi can contribute to an increased role of the organization.

The perceived high job satisfaction of employees in their work to encourage employees to improve their performance. This means that employees are able to give the role of the organization is driven by a sense of job satisfaction.

A good accounting information that is implemented in the form of relevance, timeliness and complexity of information, able to contribute directly to the improvement of employee performance also through increased organizational citizenship behavior of employees in small and medium enterprises in the province of South East Sulawesi.

Commitment to the organization's high individual less able to encourage employees to improve their performance. This means that employees are able to empirically less the role of the organization, because it is supported by engagement attitude and sense of responsibility to the organization because it is considered a thing they should do in accordance with their responsibilities as employees in small and medium enterprises in the province of South East Sulawesi.

Organizational Citizenship Behavior that employees in this study were able to give a role to the improved performance of employees in small and medium enterprises in the province of South East Sulawesi. This finding can be explained that with increased OCB existing employees in small and medium enterprises in South East Sulawesi province to increase the effectiveness of the organization, so that the important role of OCB are necessary to achieve improved performance better employee.

\section{Recommendation}

Based on the research that has been described above, there are some suggestions that need to be followed up, both for the development of knowledge for further research, especially in the field of human resource management, as well as the interests of practitioners, especially in small and medium enterprises in the province of South East Sulawesi.Based on the weaknesses of these results it can be suggested to the next researchers are as follows:

Research on organizational citizenship behavior in SMEs is still relatively limited, while its impact on the performance of employees is very large. One of the efforts to find solutions for the problems associated with the increased performance of employees in SMEs should be promoted in a similar study in a broader scope, both within the same discipline and between disciplines by developing a theory of organizational behavior in particular the theory of OCB. The complexity of factors that affect the performance of the employees need to be observed continuously. The possibility of other factors beyond the studied variables counts the opportunity to be reassessed.

Measurement of existing variables in this research that the accounting information, job satisfaction, organizational commitment, OCB and job performance by using the employee's own perception through self- 
assessment or self-appraisal for further research can measure variables with another perception is the perception of supervisors or manager for the purpose of measuring job performance and identify trends, and also can memperifikasi perception of the employees themselves for further management improvements.

Future measurement needs to examine the effect of job satisfaction on organizational commitment in which job satisfaction as the founder of an organization that is committed.

\section{Advice for Small and Medium Enterprises in Southeast Sulawesi}

This study proves that job satisfaction, accounting information, organizational commitment and OCB able to give a role to the improved performance of existing employees in small and medium enterprises in the province of South East Sulawesi. But not followed by a direct effect of accounting information on job performance. It is suggested that some of the following:

Accounting information about contributing to the thus improving job performance, companies need to create accounting information can provide ambience and comfort in working through the creation of social relations, to help each other voluntarily, giving attention to fellow co-workers better and to the existingsupervisor that the employee remain passionate and excited in the work.

Companies need to conduct training programs and continuous development of work skills that SMEs employees in Southeast Sulawesi province in the work can be more skilled so as to create employees who work effectively and efficiently in accordance with company objectives.

\section{References}

[1]. Ackfeldt, Anna L. \& Coote, Leonard V. (2000) An Investigation Into The Antecedents of Organizational Citizenship Behaviors ANZMAC 2000 Visionary Marketing for the $21^{\text {st }}$ Century: Facing the Challenge 217.

[2]. Ackfeldt, Anna L.Z Coote Leonard V. (2000). An Investigation Into the Antecedests of Organizational Citizenship Behaviour. Th 2 MAC 2000 Visionary Marketing for the 21 sektor Century. Cacing the Callengo 217.

[3]. Allen, T.D. Barnard S., Rush, M.C. dan Russell, J.E. A. 2000. Rating OfOrganizational Citizenship Behaviour; Does the Sourcek Make Prifrentce, Human Resource Management Review. 10 (1): 97-114.

[4]. Allison, Et Al. 2001. "Organizational Citizenship Behaviours and service quality as external effectiveness" journal business research vol, 56, pp, 597, 611

[5]. Alotaibi, Adam G. (2001), Antecedents of Organizational Citizenship Behavior: A Study public of Public Personnel in Kuwait, Public Personnel Management; Fall 2001; 303, ABI/Inform Research p.363.

[6]. Bambang Warsito. 2007. Pengaruh Budaya Organisasi dan Informasi Akuntansi terhadap OCB Motivasi dan Kinerja. Disertasi Program Doktor UMM Administrasi Ke Khususan Administrasi Bisnis Fak UMM Administrasi Unibraw Malang.

[7]. Barbuto, J., Brown, L., Wilhite, M., \& Wheeter, D. Justify the underlying motives of organizational citizenship behavior; A brief study of agricultural co-op workers (2001).

[8]. Bateman, TS, And Organ, D.W 1983 Job Satisfaction And The Good Soldier : The Relationship Between Affect And Empoyee Citizenship, Academy Of managemen Journal, Vol, 26, PP. 587-95.

[9]. Begum, Noorjahan 2005, The Relationship Between Social Power and Organizational Citizenship Behavior: The Meditational Role of Procedural Justice, Organizational Commitment, and Job Satisfaction In Context of A Private Commercial Bank In Bangladesh Independet University, Bangladesh April 2005.

[10]. Bodnar, G.H \& Hopwood, William S, 1995, Accounting Information Systems, Prentice Hall International, 6 Ed

[11]. Carol C Bienstock. 2003. "Organizational Citizenship behaviour and Service quality" journal of service marketing, vol, 17 No.4 2003, pp 157-178

[12]. Felfe, Jorg; Schmook, Renate; Schyns Birgit \& Six, Bernd, 2007, Does the form of employment make a difference?-Commitment of traditional, temporary, and self-employed workers Journal of Vocational Behavior 72 81-94.

[13]. Fenstein, Andrew A. 2000. A Study of Relationship Between Job Satisfaction and Organizational Commitment Among Restourant Employee.

[14]. Ferdinand. 2006. Metode Penelitian Manajemen Edisi Kedua. Penerbit: Badan Penerbit Universitas Diponegoro Semarang.

[15]. Foote, David A. and Tang, Thomas Li-Ping, 2008, Job satisfaction and organizational citizenship behavior (OCB) Does team commitment make a difference in self- directed teams? Management Decision Vol. 46 No.6, 2008 pp. 933-947.

[16]. Gibson, L. James, M. John Ivancevich, and H. James Donnely, (1997), Organisasi, Perilaku Struktur Proses, Jilid 1, Edisi Kelima, Terjemahan, Erlangga, Jakarta.

[17]. Gregory Murphy. 2002. "Job Satisfaction and Organizational commitmen as predictors of Organizational citizenship and -Role Behaviour". Journal Of Managerial Psychology, vol, 17 No 4, 2002)

[18]. Hadi Sutrino. 2004. Pengaruh Kepemimpinan Transformasional terhadap kepuasan konsumen, komitmen organisasi dan perilaku ekstra peran.

[19]. Koys, Daniel J. 2001 The effects of employee satisfaction, organizational citizenship behavior, and turnover on organizational effectiveness: A unit-level, longitudinal study Personnel Psychology. Durham: Spring 2001. Vol. 54, Iss. 1 : pg. 101,14 pgs.

[20]. La Midjan, 1990, Peranan Kelengkapan Sistem Informasi Akuntansi Terhadap Evektivitas Informasi Akuntansi Manajemen, tesis pascasarjana, Unpad Bandung.

[21]. Luthans, Fred. 2006. Organizational Behavior, Nine Edition, Irwin McGraw Hill, New York

[22]. Meyer,J.P. Stanley D.J; Hersecovith, L, and Topolnytsky. 2000 Affective, Continuance and Normative Commitment to the Organization : a Meta- Analysis of Anteseden, Correlates, and Consequances ,Journal of Vocational Behaviour,Vol 61,pp.20-52

[23]. Organ, Dennis W., Philip M. Podsakoff, Scott B. MacKenzie, (2006), Organizational Citizenship Behavior: Its Nature, Antecedents, and Consequences, First Edition, SAGE Publications Inc., California, USA.

[24]. Robbins, Stephen P. 2006. Perilaku Organisasi: Konsep, Kontroversi, Aplikasi, Edisi Kesepuluh , Prehallindo, Jakarta.

[25]. Sangmook Kim. 2006. "Public service motivation and organizational citizenship behaviour in Korea International “ journal 2006 vol 27 no 8, pp.722-740

[26]. Siegel, G.;Marconi,danHelenaR. BehavioralAccounting. South- Western Publishing Co.1989.

[27]. Smith, C.A., Organ, D.W., and Near, J.P. 1983. Organizational Citizenship Behavior: 
[28]. Suumenda Biswas and Arup Varma (2007). Psychological Climate and Indivdual Performance in India: Test of a Mediated Model Employee Relations, Vol. 29 No. 62007 PP. 664-676.

[29]. Sugiono,2004. Metode Penelitian Bisnis. Penerbit Alfabeta Bandung.

[30]. Winarno,WingWahyu,2004,Sistem Informasi Manajemen,UPPAMPYKPN, Yogyakarta.

[31]. Yusrawati,2003,PengaruhPartisipasiPemakaiTerhadapKepuasanPemakaidalam

PengembanganSistemInformasiDenganLimaFaktorKontijensiSebagai VariabelModerating, Tesis, Universitas Diponegoro, 2003.

[32]. Yoon, Makn. Hee, Suh, Jaebeom. 2003. Organiational Ociti Zenhaja Behaviour and Seris Quality as External Effectieness of Cantack Employees Jaorne of Bussiness Research 56 (2003) 597 - 611.

[33]. Yousef, A. Darwish. 2000. Satisfaction with Job Security as Predictor of Organizational Commitment and Job Performance in a Multicultural Environment.International Journal of Manpower. 19 (3): 184-194. 